\title{
Hipsters vs. Geeks? Creative workers, STEM and innovation in US cities
}

\author{
Andrés Rodríguez-Pose \& Neil Lee \\ Department of Geography \& Environment \\ London School of Economics \\ a.rodriguez-pose@1se.ac.uk; n.d.lee@1se.ac.uk
}

\begin{abstract}
Innovation in cities is increasingly regarded as an outcome of two potential inputs: scientific activity and creativity. Recent research using firm level data has suggested that actually it might be the combination of these two inputs, rather than the mere presence of workers representing each group, which matters. Yet there is little evidence on whether this relationship holds using city level data in the case of the United States (US). This paper investigates this gap in our knowledge by examining how the combination of STEM (geeks) and creative workers (hipsters) in a panel of 290 US Metropolitan Statistical Areas during the period between 2005 and 2015 relates to city level innovation. The results indicate that, although the presence of STEM workers is a more important driver of innovation than that of creative ones, the most innovative cities are characterised by a combination of the two. Hence, current policies which tend to focus mainly on either STEM or creativity may be better targeted at ensuring interactions between the two.
\end{abstract}

Keywords: Creativity, Creative Class, STEM, Innovation, Cities, United States

JEL Codes: O18, O32, O33, R12

Acknowledgements: Many thanks to Egle Pugaciauskaite for excellent research assistance. Also to Josh Siepel, Bjorn Ashiem, and participants at the Regional Innovation Policy Conference, Cardiff, November 2016. 


\section{Introduction}

"As the largely nerd-created computer industry has matured into a communications industry, it has become increasingly dependent on the very kind of creative content not normally associated with the nerd culture - storytelling, graphic arts and music."

Joel Kotkin (1997: 1)

Research on the geography of innovation has traditionally seen scientific research as the crucial input for innovation and change (Machlup, 1962; Feldman \& Audretsch, 1999). Literature in this field has highlighted the importance of investments in STEM - Science, Technology, Engineering and Mathematics - for local innovation processes, and been used to justify policies such as the development of science parks, investments in science focused universities, or efforts to attract STEM graduates (Winters, 2014; Frick et al., 2019). The dominant view remains that concentrations of highly-skilled workers in STEM occupations are vital for innovative performance (Atkinson \& Mayo, 2010). This literature, in short, suggests that innovative cities are innovative because they have plenty of geeks.

A second strand of literature has increasingly highlighted the importance of creativity for innovation. Multiple studies now focus on so-called "Creative Cities" - supporting the general view that creativity has an important role to play in urban innovation (Huggins \& Clifton, 2011; Qian, 2013; Lee, 2014; Sleuwaegen \& Boiardi, 2014; Lee \& Rodríguez-Pose, 2014a; 2016). Richard Florida's (2002) work on the creative class is the most important, but still controversial, theory in this area. Florida suggests that the most innovative cities are notable for their concentrations of creative artists, bohemians and so on (although his indicators often include STEM workers). If the creativity view is correct, innovation is not necessarily about geeky workers in science-based industries, but about creative workers in arts and design. In short, innovation is driven by hipsters.

This paper tests a third hypothesis: rather than focus on either science or creativity, the most innovative cities may be associated with the combination of these two factors. Historic discussion of innovation has often made this suggestion. For example, in 1997 Joel Kotkin argued that the computer industry was increasingly drawing on creative content to gain competitive advantage. This hypothesis also fits with the classic narrative of Apple's success, which is that it welded both high quality design and creative content with technological expertise to churn out sophisticated products. Important recent empirical work has begun to tell a similar story: Fillipetti (2011) shows the complementarity between design and R\&D in innovation; Siepel et al. (2016) use the UK Community Innovation Survey demonstrate how that firms which combine both STEM workers and arts graduates are particularly innovative. Similar results are reached by Sapsed et al. (2016) in their study of Brighton's digital economy cluster and Brunow et al. (2018) in their analysis of German firms, which also extends to an investigation of spillovers at the city level. According to this view, economic performance is not simply a question of STEM skills versus creative occupations, but the most innovative places will be those that successfully manage to combine these two types of skills. Innovation would thus benefit from the coexistence of workers with strong sciencebased knowledge and creative talent. The amalgamation of these two groups in space would generate the rich innovation ecosystems at the root of the flourishing of new ideas. In short, these studies suggest that innovation is not hipsters versus geeks, but about a combination of the two. 
At heart, this question is about human capital (Marrocu \& Paci, 2012). While most agree that this matters, "there is great uncertainty over what type of human capital matters most." (Winters, 2014: 190). Research on the link between STEM and creative occupations essentially suggests that the interaction between different forms of human capital matters. Recent work on the fusion of arts and science skills has included studies using firm interviews in a single city (Sapsed et al., 2016) and for UK firms more generally (Siepel et al., 2015). However, while empirical work has begun to consider this question using firm level data (e.g. Fillipetti, 2011; Siepel et al., 2016; Sapsed et al., 2016) and has investigated firm-level processes and spillover effects at the city level (e.g. Brunow et al., 2018), there are still some significant gaps in the evidence on this topic. Firstly, the research has almost exclusively been focused at the level of the firm. Studies have used firm as the unit of observation and innovation indicators drawn from firm level surveys. Secondly, research has mainly been focused on establishing whether the presence of STEM or creative workers is more important for innovation, rather than on assessing the extent to which the combination of these two types of workers can be the main driver of innovation at city level. While there is a growing number of studies considering the role of both STEM and creative occupations on innovation in cities and regions (Stam et al., 2008; Sleuwaegen \& Boiardi, 2014; Lee \& Rodríguez-Pose, 2014a; Winters, 2014b), little research has considered the interaction between these two categories.

This paper considers these questions and so addresses these evidence gaps. It distinguishes between a set of creative and STEM occupations called, respectively and with tongue in cheek, "Hipsters" and "Geeks". It then uses a dataset of 290 US metropolitan statistical areas (MSAs) to investigate the relationships between geeks, hipsters, and the interaction between the two in innovation at the city level. We find suggestive evidence that, although at first sight the presence of STEM workers is a more important driver of innovation than that of creative ones, the most innovative cities are those that combine the two. It is the combination of both hipsters and geeks - rather than hipsters or geeks on their own - that characterises the most innovative cities.

Our focus in this paper is on city level processes. We argue that the diverse mixes of economic activity provided by urban environments can allow the successful development of new ideas. This idea is central to the literature on the economic benefits of cities, dating back at least to Jacobs (1969), and underpins the view that proximity can bring complementary economic activity together, stimulating innovation (Feldman and Audretsch, 1999). While a city-level focus means that we cannot show the micro-level processes through which firms may integrate creative and STEM occupations, nor can we show causality, we are able to capture the city-level diversity processes which are important in theory.

The remainder of this paper is structured as follows. We begin by setting out the existing literature on the role of STEM and creative occupations in innovation, and more recent work which suggests that the interaction between the two (sometimes called STEAM) may be particularly important for innovation. We then set out the variables we use to test these relationships and develop a model of innovation at a local level. Next, we discuss our results and their implications. Finally, we conclude with suggestions for research and policy. 


\section{The drivers of innovation in cities: Creativity versus STEM}

The literature on the importance of STEM workers for innovation is well established. Classic studies on urban and regional innovation processes have highlighted the role of the science base in innovation processes (e.g. Feldman \& Audretsch, 1999). As a result of this, most research on innovation in cities tends to include some proxy of scientific activity, be it expenditure on scientific research or an indicator of human capital in scientific occupations, commonly STEM skills (Science, Technology, Engineering, and Maths). Based on the results of existing research, increasing the stock of STEM workers in an economy has become usually regarded as vital for innovation and growth and a common ingredient of virtually all innovation policies (Atkinson \& Mayo 2010).

In contrast to the longstanding recognition that STEM is important, the idea that creativity in cities matters for innovation has only become popular more recently. The most influential work in this area has come from Richard Florida (2002; 2005), who has argued that the presence of a "creative class" of knowledge workers is becoming a must for the economic dynamism of cities and regions. Florida's theory has increasingly articulated innovation policy, especially at the urban level (Florida, 2014; Gabe, 2006). However, it remains - like many other theories - controversial amongst academics (Glaeser, 2005; Peck, 2005; Marrocu $\&$ Paci, 2012). Questions abound about the definition of the creative class (Glaeser, 2005), the prioritization given to this group by policy-makers (Atkinson \& Easthope, 2009), and the best way for local and regional decision-makers to attract this group (Houston, Findlay, Harrison, \& Mason, 2008; Brunow et al., 2018). One controversy in the creative class literature has been the grouping of both creative workers in the traditional sense, such as artists, and those who do less obviously 'creative' jobs. For Florida, creativity was about what you do rather than your qualifications - hence the importance of occupational measures (Boschma \& Fritsch, 2009). But creativity is an important part of occupations beyond those in the creative industries - workers in STEM can also often perform a raft of creative activities.

Empirical work has tended to - in general - support a link between certain types of creative people and innovation and economic development (Marlet \& Van Woerkens, 2007; Clifton, 2008; Stam, de Jong, \& Marlet, 2008; Boschma \& Fritsch, 2009; Huggins \& Clifton, 2011). This work has, at times, had a spatial dimension. Marrocu and Paci (2012) for example, focused on regions of the European Union. However, the great majority of the research has resorted to firm level data to demonstrate the importance of creative workers for innovation. For example, Lee \& Rodríguez-Pose (2014a) use firm level data for the UK to show that small firms in cities with high concentrations of jobs in creative industries have been more likely to introduce new to the market product and process innovations than those in other local economies (rather than new to the firm type of innovation) (see also Lee \& Drever, 2014). Their analysis highlights that the presence of creative occupations is more important than being in a creative industry. Brunow et al. (2018), using firm level data for the whole of Germany, find that both creative and STEM workers contribute to innovation within the firm, but that the influence of STEM employees is way larger. They also report impacts that go well beyond the walls of firm itself. Larger shares of STEM workers, mainly in South Germany generate large spillover effects and influence innovation in neighbouring areas. In their view, innovation in Germany, while depending on both types of workers, owes more to the existence and concentration of STEM employees.

The contributions cited above are good explanations for why either STEM or creativity may help innovation. Overall, the empirical research conducted on this topic has tended to neglect 
the mechanisms and effects of the potential interaction of both types of workers exclusively at a city level, ${ }^{1}$ while why the combination of hipsters and geeks in reduced geographical spaces may represent a boon to innovation still requires further explaining.

Theoretical work in both innovation studies and economic geography does, however, provide some guidance for why this might be the case. The most important and direct recent contribution in this area is from Siepel et al. (2016). These authors use the UK Community Innovation Survey (CIS) to investigate businesses that use "fused skills" by which they mean both arts and science skills. They argue that, while arts and STEM skills are important for innovation independently, in isolation they cannot create the necessary synergies that lead to new ideas, products, and processes. In their view, it is their interdependence which helps bring innovations, in general, and radical innovations, in particular, to market. The effect of the combination of both creative and science skills - which they limit at $3 \%$ of innovation is not particularly large, but it is robust to different specifications and controls.

A similar study comes from the Brighton Fuse project (Sapsed et al., 2016), which considers the idea of fused businesses, those that "combine creative art and design skills with technology expertise" ( $p$ p 1). This is a detailed study, which shows the importance of a cluster of skilled workers, entrepreneurs and networks in terms of creating innovation. They show that the innovation resulting from this fused development:

"is often realised in new forms of service, new interactive content, new interdisciplinary combinations, or the counterintuitive lateral thinking we described earlier in new social media and digital marketing campaigns. These require analytical understanding of the audience/consumer, as well as the communications, media production and aesthetic sensibilities to lure them into engaging"

(Sapsed et al., 2016: 35).

Consequently, the creation of industry echoes systems where hipsters and geeks interact on a regular basis creates the breeding grounds for new ideas and for the development and implementation of all types of innovation. In brief, the increasing view is that hipsters need geeks, but geeks also need hipsters to create the right environment for new ideas and innovations to take hold. But, is this really the case?

Earlier studies have also provided evidence which is consistent with, if not directly focused on, the existence of a fusion effect between creative and scientific workers. For example, Vinodrai (2006) investigates the role of workers in design in Toronto. She argues that creative workers tend to be in short-term, project-based employment and so their influence is not: "limited to these industries, but also extends into other sectors of the economy that benefit from access to the same" (237). This qualitative finding has also been replicated in

\footnotetext{
${ }^{1}$ Brunow et al. (2018) is possibly the study that in terms of design covers the most similar ground. In this research Brunow et al. (2018) use data for firms in the whole of Germany, where as the focus of the current paper is limited to US cities. The results are also different. In Brunow et al. (2018) the effect of STEM accrues fundamentally in rich areas - many of them rural, small towns, or medium-sized cities. The largest German urban agglomerations generally concentrate far greater shares of creative workers. In the US, by contrast, STEM workers concentrate in cities to a far greater extent than in Germany. This makes US large cities more innovative and dynamic from an economic perspective relative to the rest of the country than in Germany. There, the two largest urban agglomerations - the Ruhr and Berlin - have not performed particularly well relative to the rest of the country and in comparison to most of the largest cities in the US in recent decades.
} 
quantitative work. Bakshi and McVittie (2009) do so using input-output tables, finding that the creative industries aid innovation in the rest of the economy. Focusing on creative occupations, Lee and Drever (2013) underline that London firms in sectors which employ more workers in creative occupations are more innovative. Similar spillover effects into the wider economy are uncovered by Lee and Rodríguez-Pose (2014b).

At the city level, the conceptual ideas of the separate literature around combinations of knowledge bases is also helpful. This literature is not directly focused on STEM or creative human capital, but yields relevant insights. Starting from the assertion that there are multiple forms of knowledge, work in this area distinguishes between different forms of knowledge: analytic (scientific), synthetic (practical), and symbolic knowledge (based around aesthetics). Grillitsch et al. (2016) suggest that it is the combination of different forms of knowledge is at the root of innovation: "new ideas often occur when analytical, synthetic and symbolic knowledge intertwines" (page 1). Testing this hypothesis using Swedish data, they find that regions with combinations of different types of knowledge in place that are more likely to innovate: "Symbolic knowledge turns out to be a catalyst of innovation only if combined with analytical knowledge." (page 27). Hence, the combination of different forms of knowledge is crucial for the creative process in Sweden, not only within the firm, but also for activities that take place in the region in which the firm is located.

While it is clear to see how a combination of STEM and creative skills may help at firm level, the challenge for these explanations is linking the combination of these activities with innovation at a city level. We know that innovation is often the result of relatively few actors, so assuming that a mix will lead to innovation at a local level risks an ecological fallacy. There are two important justifications for focusing on the city level. The first is that there may be knowledge spillovers, untraded exchanges of knowledge between actors at a local level which may allow the productive fusion of these forms of activity (Storper \& Venables, 2004). Second, the prosaic link is that, if there are concentrations of creative occupations near STEM workers, this is a necessary condition if workers are to be co-located in the same office (although some firms may site creative functions in different places to STEM functions). Thirdly, the creative industries tend to co-locate near to sources of market demand, with city level co-location indicating an interaction between tech-industries or institutions and local actors. Given this, there are clear channels suggesting that city-level effects may operate through which co-location of creative and STEM activities can help innovation.

\section{Data and descriptive statistics}

To test whether city level innovation is associated with hipsters, geeks, or their combination, we conduct an analysis of urban innovation in the US, covering the 290 largest urban areas in the country during the period between 2005 and 2015.

\section{The American Community Survey}

Our main data source is the American Community Survey (ACS), 2005-2015. This is a largescale annual sample survey of almost 3 million households per year (see Spielman \& Singleton, 2015). We access the microdata via the IPUMS service at the University of Michigan (Ruggles et al., 2018). This contains highly detailed information on individual characteristics of the population, such as demographics, education, and occupation. The ACS 
data are constructed to allow statistics to be calculated at the Metropolitan Statistical Area (MSA) scale, defined using the 2013 Office of Management and Budget delineations. Each MSA has a central core urban area, and also contains neighbouring counties with strong commuting links. They therefore represent a reasonable approximation of an urban economy. We amalgamate county level population and patenting data to the same scales to match these boundaries. The final sample contains 295 MSAs, although five of the smallest MSAs are dropped from the final analysis, due to lack of complete datasets for all the variables.

\section{Defining innovation}

There are many indicators of innovation, each of which captures subtly different aspects of the creative process (Archibugi \& Pianta, 1996). Unfortunately, none can encompass the full spectrum of innovative activity. Because the attention of this paper is on the merging of scientific and design focused innovation, as in the technological products cited by Joel Kotkin in the quote cited in the introduction, we use patenting as our measure of innovation. Patenting, in addition to its focus on technology, has the merit of being consistently employed in much academic research, reflecting innovations of at least some significance (few would patent a trivial innovation), and being available at the MSA level and, thus, comparable for the whole sample during the period of analysis.

However, the limitations of using patenting are also obvious. Only certain types of innovation in specific sectors are likely to be patented. More radical product innovations than process, organisational, or marketing innovation ends up being patented. Most new process innovations will therefore go unregistered in our analysis, while only some forms of new product will be fully considered. It may also be biased by sector as there will be more patenting in manufacturing than in services, and even within manufacturing the pharmaceutical industry will patent much more than, for example, in aeronautics. A number of sectors, across the whole spectrum of the economy, are more prone to protect intellectual property in other fashions. Hence, our measure of innovation will favour activities and sectors where scientific workers (geeks) are more present than those types and areas of innovation where the role of creative workers (hipsters) is more relevant. While these limitations need to be considered in this study and the results of the analysis examined in this light, patenting - at least in the case of US metropolitan areas - still represents the best available sub-national indicator of innovation.

\section{Defining STEM and Creative Occupations}

The focus of this paper is on what people do, rather than what they studied or the sectors they work in (Boschma \& Fritsch, 2009; Vallance, 2015). The definition of STEM occupations comes from the US Bureau of Labour Statistics (BLS) (see Jones, 2014). Essentially this is four occupational categories: Life and Physical Science, Engineering Mathematics, and IT occupations; Social Science Occupations; Architecture Occupations; and Health Occupations. We use this definition partly because it is relatively well-established, but also because, as a policy focused definition, the results are relevant for policy-makers. However, we make a number of adaptations - in particular, as Architects and Urban Planners tend to be seen as a crucial part of the creative industries, we include them as creative occupations. A full list of occupations included in "STEM" is included in Table 1. 
Advertising and promotions managers; Public relations and fundraising managers; Marketing and sales managers; Architects, Except Naval; Urban and Regional Planners; Model makers, patternmakers, and molding machine setters, metal and plastic; Metal Furnace Operators, Tenders, Pourers, and Casters; Tailors, Dressmakers, and Sewers; Cabinetmakers and Bench Carpenters; Furniture Finishers; Designers; Producers and Directors; Artists and Related Workers; Photographers; Broadcast and Sound Engineering Technicians and Radio Operators, and media and communication equipment workers, all other; Editors; Writers and Authors; Technical Writers; Librarians; Archivists, Curators, and Museum Technicians; Actors; Announcers; Entertainers and Performers, Sports and Related Workers, All Other; Dancers and Choreographers; Musicians, Singers, and Related Workers
Computer scientists and systems; Computer network architects, Information security analysts, Web developers; Computer programmers; Software developers, applications and systems software; Computer support specialists; Database Administrators; Network and Computer Systems Administrators; Actuaries; Miscellaneous mathematical science occupations, including mathematicians and statisticians; Operations Research Analysts; Agricultural and Food Scientists; Biological Scientists; Conservation Scientists and Foresters; Medical Scientists, and Life Scientists, All Others; Astronomers and Physicists; Atmospheric and Space Scientists; Chemists and Materials Scientists; Environmental Scientists and Geoscientists; Physical Scientists, All Other; Economists; Psychologists; Miscellaneous Social Scientists; Agricultural and Food Science Technicians; Biological Technicians; Chemical Technicians; Geological and Petroleum Technicians; Nuclear Technicians; Social Science Research Assistants

Since the work of Florida $(2002 ; 2005)$ there has been increased interest in the use of occupational measures of creativity. While there is no perfect predictor of creativity, and many workers in creative occupations may not perform particularly 'creative' activities, over time a limited number of definitions of creative activities have become commonly used in the literature. The use of an occupational measure of creative activities also makes sense because of the increased interest in occupational targeting. Yet defining creative activities, because of the sheer breadth of the sectors they touch upon, remains far more controversial than defining STEM activities (Winters, 2014a).

As there is no US focused definition of creative occupations, we resort to one of the tighter and more specific notion of creative occupations: that put forward by the UK government. The UK definition is then cross-walked to make it comparable with the definitions used in the 
ACS (see Lee \& Rodríguez-Pose, 2014a for an application). This gives a set of occupations which can be roughly included in 10 categories: Advertising; Architecture; Crafts; Design; Designer Fashion; Video, film and photography; Music and the visual and performing arts; Publishing; Software and electronic publishing; Radio \& TV. ${ }^{2}$

\section{Descriptive statistics}

Table 2 shows the MSAs which score highest on the two measures. The highest shares of Hipsters are to be found in Santa Fe and Bend-Redmond, both small MSAs which are well known location for the arts. Other large cities, including San Francisco, Los Angeles, Austin and New York form part of the MSAs in the list, which also includes small university towns such as Ithaca. Geeks display a similar geography, with San Jose-Sunnyvale-Santa Clara (home to Silicon Valley) high, along with other areas with famously robust tech economies such as Raleigh (NC). Two MSAs appear in both lists: San Francisco-Oakland-Hayward, CA, and Ithaca, NY.

Table 2. Highest share of creative and STEM occupations, 2015

\begin{tabular}{|c|c|c|c|c|c|}
\hline Rank & MSA Name & Hipsters $(\%)$ & Rank & MSA Name & Geeks $(\%)$ \\
\hline 1 & Santa Fe, NM & 7.3 & 1 & $\begin{array}{l}\text { San Jose-Sunnyvale-Santa } \\
\text { Clara, CA }\end{array}$ & 11.7 \\
\hline 2 & Bend-Redmond, OR & 7.3 & 2 & Ithaca, NY & 8.9 \\
\hline 3 & $\begin{array}{l}\text { San Francisco-Oakland- } \\
\text { Hayward, CA }\end{array}$ & 5.3 & 3 & Champaign-Urbana, IL & 8.8 \\
\hline 4 & $\begin{array}{l}\text { Los Angeles-Long } \\
\text { Beach-Anaheim, CA }\end{array}$ & 5.3 & 4 & $\begin{array}{l}\text { Washington-Arlington- } \\
\text { Alexandria, DC-VA-MD- } \\
\text { WV }\end{array}$ & 8.3 \\
\hline 5 & $\begin{array}{l}\text { Burlington-South } \\
\text { Burlington, VT }\end{array}$ & 4.9 & 5 & $\begin{array}{l}\text { San Francisco-Oakland- } \\
\text { Hayward, CA }\end{array}$ & 7.9 \\
\hline 6 & Pittsfield, MA & 4.8 & 6 & Raleigh, NC & 7.6 \\
\hline 7 & Austin-Round Rock, TX & 4.3 & 7 & Trenton, NJ & 7.3 \\
\hline 8 & $\begin{array}{l}\text { New York-Newark- } \\
\text { Jersey City, NY-NJ-PA }\end{array}$ & 4.3 & 8 & Bloomington, IL & 7.1 \\
\hline 9 & Bloomington, IN & 4.2 & 9 & $\begin{array}{l}\text { Blacksburg-Christiansburg- } \\
\text { Radford, VA }\end{array}$ & 6.9 \\
\hline 10 & Ithaca, NY & 4.2 & 10 & Ann Arbor, MI & 6.9 \\
\hline
\end{tabular}

Source: American Community Survey via Ruggles (2018).

Next, we consider the descriptive statistics of the creative occupation (hipster) and STEM occupations (geek) versus the patenting dependent variable. In both cases there is a strong, positive relationship between the occupational measure and patenting (with $p<0.001$ ). Figure 1 presents the relationship between the two occupational measures, with the size of the markers indicating the number of patents per capita. In contrast to what was reported by Brunow et al. (2018) for the case of Germany, where creatives were more urban and STEM workers often concentrated in rich areas, in the US there is a high correlation between these two $(0.63, p<0.001)$. The size of the markers represents the number of patents per capita in

\footnotetext{
${ }^{2}$ There are some changes in the occupational classification over the period we study, which we account for in our definitions. Fortunately these involve only switches within our two categories and do not prevent us producing an average for each year.
} 
each city: there is a positive relationship, as cities with higher shares of both values tend to have higher patents per capita. We note that both of these indicators have been increasing over time, with the average share of MSA workforces who are 'hipsters' increasing from $2.29 \%$ in 2005 to $2.32 \%$ in 2015 , and a larger increase in the share of 'geeks' from $2.64 \%$ to $2.94 \%$. As discussed in other literature, patenting in US cities was on an upward trend in this period (see Rothwell et al., 2013).

Figure 1. Creative occupations, STEM and innovation, 2015

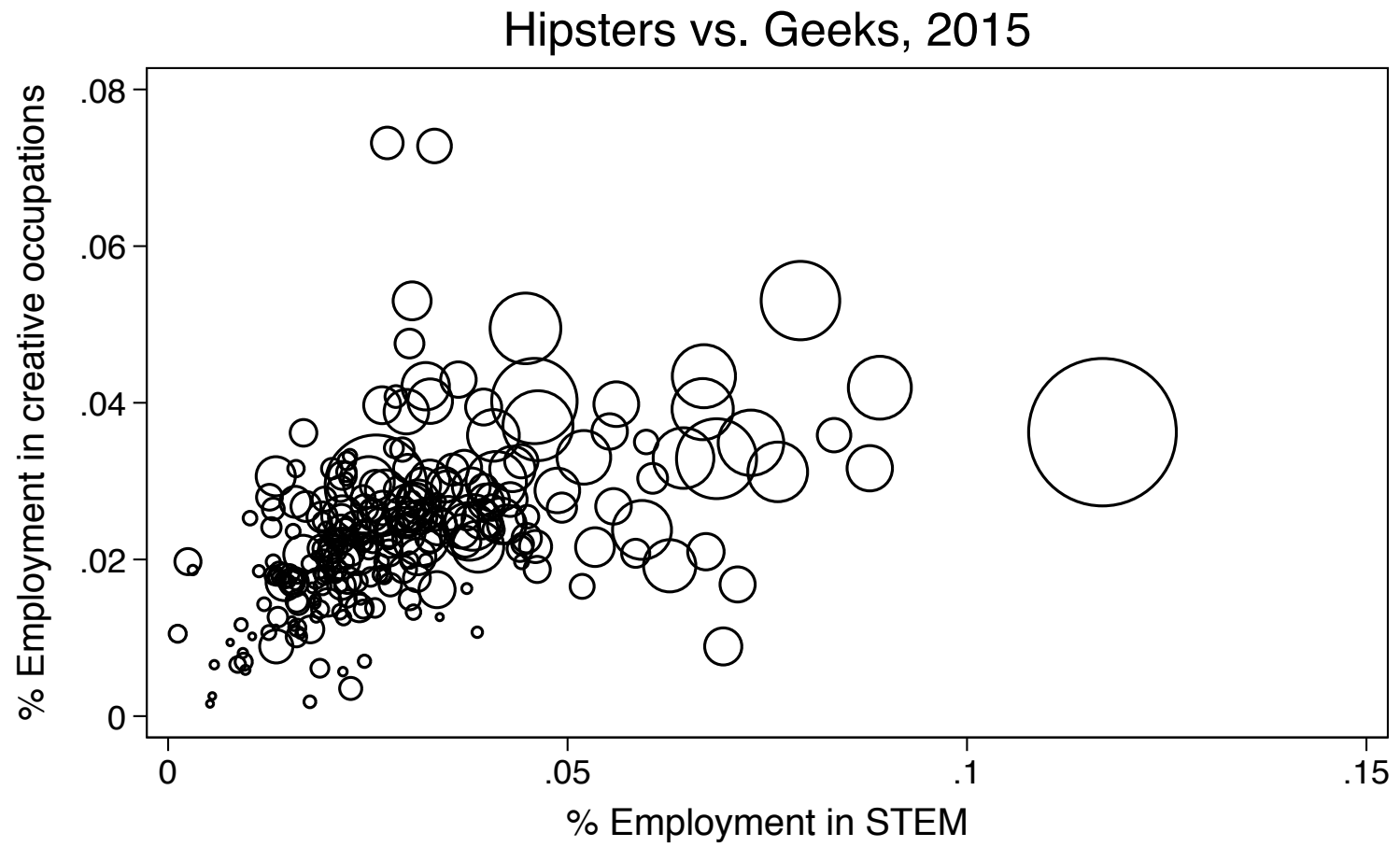

Circle size determined by Patents Per Capita 2015

\section{Modelling innovation}

\section{The model}

The model is a variation of the classic knowledge production function, where the output of innovation (patents) is determined by a set of explanatory variables which relate to cityspecific factors. More formally, it is given by equation (1):

$$
\mathrm{K} c, t=\mathrm{f}(\text { STEM, Creative, Controls })
$$

Where $\mathrm{K}$ is the output of knowledge (patents) in city $c$ at time $t$; STEM is the share of occupations likely to be taken up by workers with training in science, technology, engineering and mathematics; Creative is the share of workers in creative occupations; and Controls is a set of controls for alternative factors likely to have an influence on innovation at the urban level. Adapting this equation for a regression analysis model, gives the following result:

Innovation $_{i, t}=\alpha+\beta_{1}$ STEM $_{i, t}+\beta_{2}$ Creative $_{i, t}+\beta_{3}$ STEM $^{*}$ Creative $_{i, t}+\beta_{4}$ Controls $_{i, t}+\varepsilon$ 
for MSA $i$ in time $t$. The dependent variable is patents per capita. The core variables of interest are the share of employment in STEM occupations (STEM), the share in creative occupations (Creative), and their interaction (STEM*Creative). The controls account for classic alternative explanations of local innovation: the size of the MSA, proxied by the natural logarithm of the population; income per capita; the share of men in the population; the share of non-white; the average age; the share of the working population with an MSc or a $\mathrm{PhD}$ degree; and the unemployment rate.

The first of these controls - the size of the MSA - is intended to control for one of the factors that has been most constantly highlighted as a key source innovation. Both in the new economic geography and in urban economics innovation is associated with agglomeration and density. Bigger cities concentrate the critical mass of firms and skilled workers supposed to be at the root of the knowledge generation that is behind innovation and of the so-called buzz of the city, which helps diffuse knowledge (Storper \& Venables, 2004). Moreover, agglomeration economies provide large cities with three sets of advantages: knowledge sharing; improved matching and so specialisation in the labour, product, or service markets; and improved sharing of infrastructure (Marshall, 1919; Duranton \& Puga, 2005). These should increase innovation in large cities. Yet while we expect larger cities to be more innovative, this may be counterweighted - as indicated by a growing volume of literature (Fitjar \& Rodríguez-Pose, 2011; Shearmur, 2015 Grillitsch \& Nilsson, 2015) - by the benefits of locating in medium-sized and smaller cities or, even, in rural areas. More innovative firms are also considered to cluster in richer areas, which, in turn, they contribute to make wealthier. Hence, the introduction of income per capita at the MSA level.

There are also multiple contributions that put diversity at the heart of innovation (Feldman \& Audretsch, 1999; Østergaard et al., 2011; Nathan \& Lee, 2013; Qian, 2013). Diverse populations tend to be particularly good at creating new ideas. A wide body of empirical research now interrogates these ideas, generally finding a positive link (Nathan \& Lee, 2013; Lee, 2015). To account for this, we include a variable for the share of males and non-whites in the population. We expect that a greater share of men could be detrimental for innovation, which - as Østergaard et al. (2011) show - is facilitated by gender diversity, while more overall diversity, proxied by a greater presence of non-whites, would facilitate the generation of new knowledge and innovation (Nathan \& Lee, 2013; Lee, 2015).

Workforces also become less innovative as they age. Younger people may be more likely to work in dynamic, innovative parts of the economy, and to apply their ideas to the creation of innovation (Acemoglu et al., 2014). In contrast, older people may remain in parts of the economy which are past their dynamic period. We include a variable for the average (mean) age of the population to control for that.

High skills in the labour force are seen as one of the key inputs into innovation. These are represented by the share of the working population holding a $\mathrm{PhD}$ or an MSc. Given that the argument set out in section 2 is one about the use of human capital, these controls help avoid the potential of a confounding relationship. However, we exclude those who are in either of our two occupational categories (STEM or creative occupations) from this definition.

Finally, we also include a measure of general economic dynamism - the unemployment rate. We do this to control for the general state of the economy. We expect unemployment to be negatively related to innovation, although the causality will run both ways. 


\section{Basic results: Pooled Cross-section}

We first investigate the OLS relationship between creative occupations, STEM occupations and innovation. We estimate the model as a simple pooled cross-section at first, to show the basic relationships between variables. The results are given in Table 3, which includes city and year fixed effects, but no controls, in order to focus on the key independent variables of interest.

Table 3. Pooled OLS results: Connection between creative and STEM occupations and innovation

\begin{tabular}{|c|c|c|c|c|c|}
\hline $\begin{array}{l}\text { Dependent variable: } \\
\text { Patents per } 1,000 \text { population }\end{array}$ & $\begin{array}{l}(1) \\
\text { Pooled } \\
\text { OLS } \\
\end{array}$ & $\begin{array}{c}(2) \\
\text { Pooled } \\
\text { OLS } \\
\end{array}$ & $\begin{array}{c}(3) \\
\text { Pooled } \\
\text { OLS } \\
\end{array}$ & $\begin{array}{c}(4) \\
\text { Pooled } \\
\text { OLS } \\
\end{array}$ & $\begin{array}{c}(5) \\
\text { Pooled } \\
\text { OLS } \\
\end{array}$ \\
\hline Hipsters (creative occupations, \%) & $\begin{array}{l}0.0829 \\
(0.543)\end{array}$ & & $\begin{array}{l}0.0791 \\
(0.542)\end{array}$ & $\begin{array}{c}-2.013 * * \\
(0.952)\end{array}$ & $\begin{array}{l}-1.190 \\
(0.732)\end{array}$ \\
\hline Geeks (STEM occupations, \%) & & $\begin{array}{c}1.859 * * * \\
(0.522)\end{array}$ & $\begin{array}{c}1.858^{* * *} \\
(0.522)\end{array}$ & $\begin{array}{c}-0.0646 \\
(0.889)\end{array}$ & $\begin{array}{l}-0.992 \\
(0.682)\end{array}$ \\
\hline Interaction: Hipsters \& Geeks & & & & $\begin{array}{c}80.50 * * * \\
(30.16)\end{array}$ & $\begin{array}{l}61.68 * * * \\
(23.34)\end{array}$ \\
\hline Constant & $\begin{array}{c}0.400 * * * \\
(0.0442)\end{array}$ & $\begin{array}{c}0.349 * * * \\
(0.0438)\end{array}$ & $\begin{array}{c}0.347 * * * \\
(0.0465)\end{array}$ & $\begin{array}{c}0.395 * * * \\
(0.0499)\end{array}$ & $\begin{array}{r}0.422 * * * \\
(0.0380)\end{array}$ \\
\hline Observations & 2,888 & 2,888 & 2,888 & 2,888 & 2,866 \\
\hline Number of MSA & 290 & 290 & 290 & 290 & 285 \\
\hline City FE & YES & YES & YES & YES & YES \\
\hline Time FE & YES & YES & YES & YES & YES \\
\hline $\mathrm{R}^{2}$ & 0.929 & 0.929 & 0.929 & 0.929 & 0.916 \\
\hline Adjusted $\mathrm{R}^{2}$ & 0.921 & 0.921 & 0.921 & 0.921 & 0.906 \\
\hline F test & 112.8 & 113.3 & 112.9 & 112.8 & 93.17 \\
\hline Prob $>F$ & 0 & 0 & 0 & 0 & 0 \\
\hline
\end{tabular}

Columns 1 and 2 introduce the variables of creative (Hipsters) and STEM (Geeks) occupations individually. The results indicate that the presence of geeks is more likely to be associated with innovation than that of hipsters. The presence of STEM occupations also trumps that of creative ones when they are introduced simultaneously in the analysis (Column 3). While there is a clear positive relationship between STEM and innovation, at least in this cross-sectional framework, creative occupations seem to have no relationship with innovation. Column 4 introduces the interaction between both factors. In this case, the sign of both the basic creative and STEM variables changes: when accounting for the presence of geeks alone, it does not matter, but there is a negative and significant association between the presence of hipsters and urban patenting. The big novelty is, however, the sign of the interaction. It is positive and strongly significant. These results hint that, while geeks represent a direct and rich source of innovation in the US, having high shares of more creative hipsters is also potentially important, but in a more indirect way. Cities are most innovative where they have a combination of the two. Both geeks and hipsters are, thus, 
central for innovation, but in fundamentally different ways. ${ }^{3}$ One concern is that this may be driven by the skewed distribution outlined in Figure 1. To address this concern, column 5 excludes the 5 MSAs with the highest patenting per capita. This reduces the size of the effect, but does not change the key result on the interaction term.

\section{Panel results: Hipsters versus Geeks}

We next consider whether these results remain in a panel regression model, using fixed effects, which can control for unobservable but time invariant factors. We begin, as in the OLS model, by including both variables separately. All regressions in Table 4 contain time dummies to account for cyclical variation in patenting rates. The results of the OLS analysis are reproduced in Columns 1 to 4 of the fixed effects analysis. Once again, the presence of geeks in a city is positively and significantly associated with innovation, while that of hipsters appears as insignificant. This result is reproduced when both variables are considered jointly. The introduction of their interaction stresses the value for cities of having both a sizable presence of geeks and hipsters in their workforce.

The analysis is estimated with controls in columns 5 to 8 . The introduction of the controls marginally weakens the magnitude of the association between both types of workers and innovation, but the signs and significance remain the same. Even when controlling for a large number of factors behind innovation, a healthy combination of STEM and creative workers is fundamental for the innovation capacity of US cities. As with the results without controls, the interaction between creative workers and STEM workers is positive and statistically significant.

To plot out this relationship further, Figure 2 shows the predicted probabilities for the impact of STEM workers on innovation in cities with different levels of creative employment. The central line presents the fitted values, the shaded error gives confidence intervals at the $10 \%$ confidence level. Again, these show - with some caution - that there is a positive relationship between STEM and innovation, but this only applies in cities with higher shares of creative occupations. The effect is only likely to be consistently positive above a relatively high share of creative employment, one reached by relatively few cities. While this result is not clear cut, it does suggest an interactive effect does exist.

\footnotetext{
${ }^{3}$ A referee raises a useful question - can these results be explained by the presence of major universities in the MSA? The presence of a University should be captured by the MSA fixed effects and we also control for share of the workforce who have Masters or PhD level qualifications. However, conduct a further test by running a cross-sectional regression for the year 2015, using the same variables as Table 3, column 4 . We incorporate a variable for the number of post-secondary education facilities per capita, using data from the Homeland Infrastructure Foundation (2019) data which is geocoded, and then converted to MSA level data. Inclusion of this variable does not change our basic result - the interaction between hipsters and geeks is still positive and statistically significant $(\mathrm{P}<0.01)$.
} 
Figure 2. Interaction plot: Impact of STEM occupations on innovation, with different levels of creative occupations

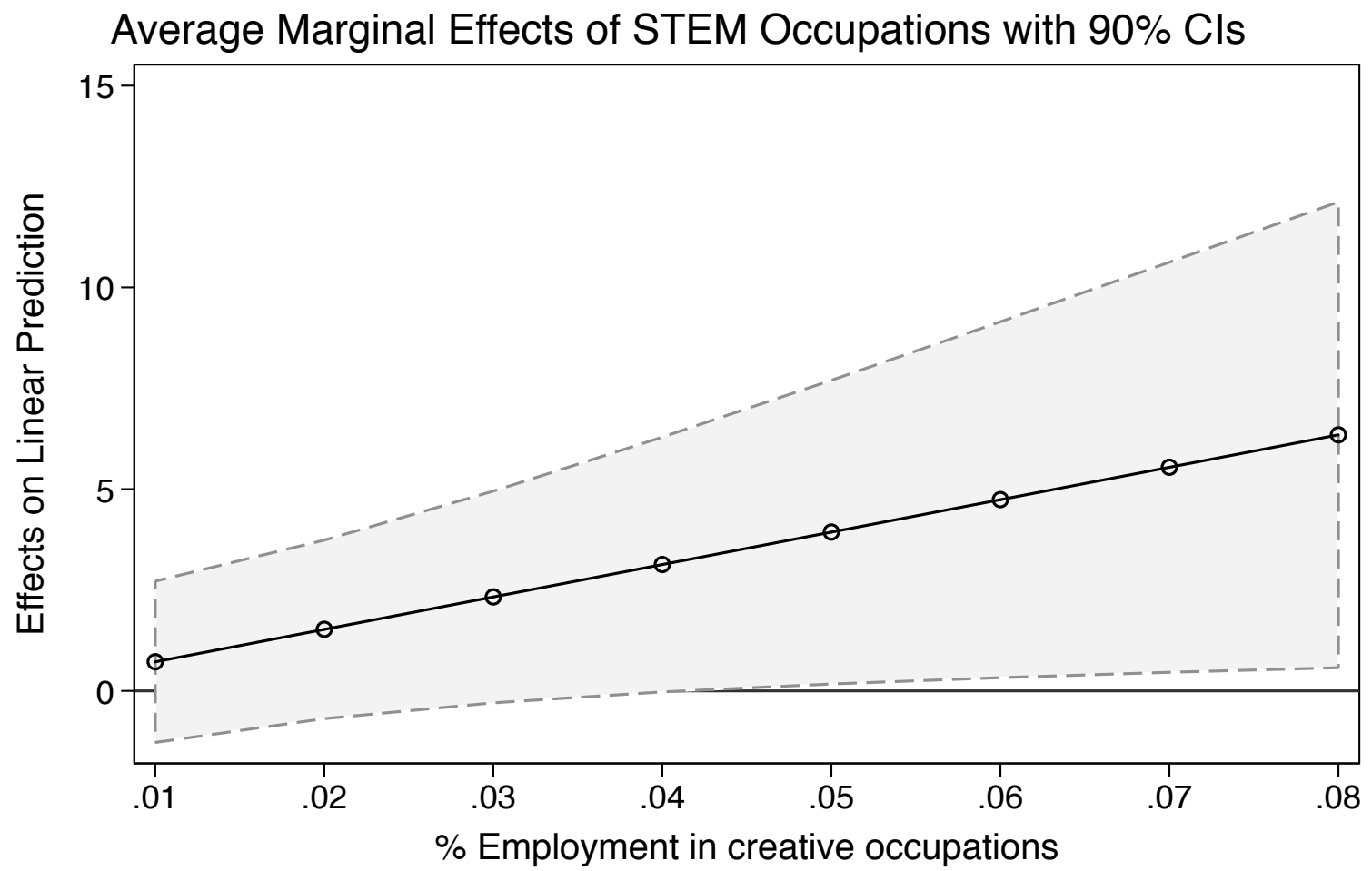

The controls generally conform to expectations (Table 4). Innovation in the US takes place in richer cities, but not necessarily in bigger ones. The sign of the coefficient for income per capita is positive and significant, while that of the population of the MSA is, in contrast with the dominant narratives, insignificant. Innovation is also associated with younger, less maledominated, and more diverse cities. The presence of highly skilled workers spurs innovation, while levels of unemployment display and insignificant coefficient. 


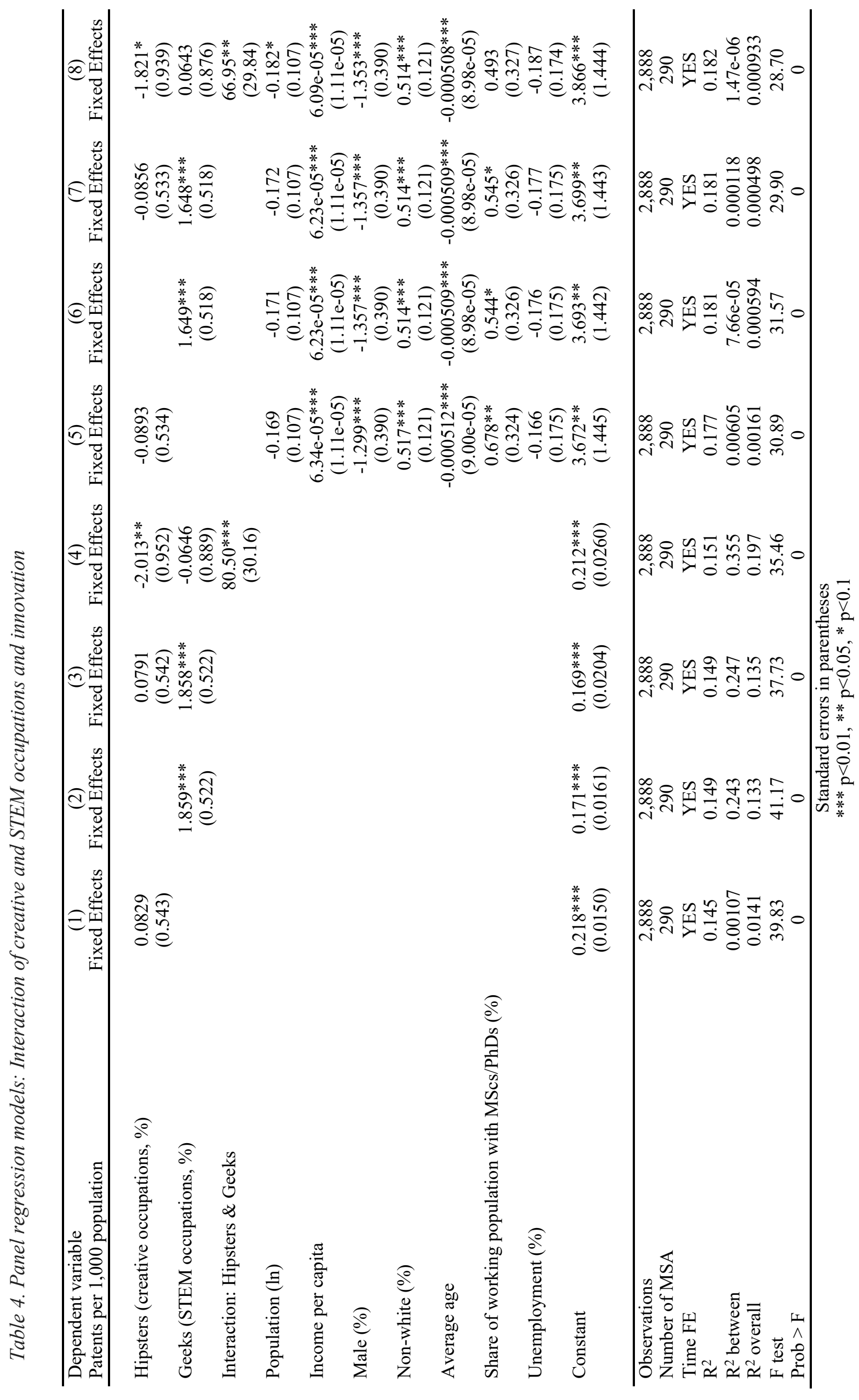




\section{Conclusions and implications}

Two important literatures in innovation studies are focused on the role of STEM in innovation and on the role of creativity in cities. This paper has argued that the interaction between creative workers and those in STEM is an overlooked determinant of the geography of innovation. Building on recent research on the fusion of arts and science skills (e.g. Siepel et al., 2016) and contributions in economic geography, which suggest that combinations of activities matter for innovative performance (Grillitsch et al., 2017), this paper has tested the impacts of STEM and creative occupations in cities on innovation, alongside their interaction. While, like in most research, we need to be cautious about our results, they point to the presence of a non-negligible interactive effect between STEM and creative occupations - a finding which supports the existing evidence based on firm level processes (Brunow et al., 2018). STEM alone may be positively linked with innovation, but the biggest effect occurs in combination with many creative activities that can help develop and market these innovations. Creative activities in isolation seem to have a lower connection to urban level innovation in the US than what has been indicated by the recent literature. However, the most innovative cities have a combination of the two: Geeks are more effective when working alongside hipsters in cities. Hence, hipsters need geeks, but geeks also need hipsters. Each group, on its own, makes a far lower contribution to the innovative capacity of a city.

The focus of this study is on combinations of different types of occupations and economic activity, and the fact that there can be additive effects from complementary forms of activity. Our results should be seen in the context of other micro-level studies. For example, Brunow et al. (2018) argue that local decision makers should focus on STEM workers, and - if there has to be one focus - this is true in our results as well. But given that econometric work such as Siepel et al. (2019) show the benefits of interacting STEM and creative workers at the city level, we would argue further that policy-makers should think about combinations of occupations at a city level. This is a challenging view for decision-makers, who - from necessity - often focus on specific sectors in isolation. These findings suggest that a standalone creative quarter, or a new creative activity separated from other activities, is less likely to be successful than a balanced local strategy which looks at the potential interactions between related sectors. The notion of the policy mix is useful here, and any attempt to use creativity for local economic development may need to include both attempts to stimulate a specific type of occupation or sector and link them to other areas of the economy. The evidence here suggests the importance of a local dimension to these relationships, meaning that the local policy mix is likely to be crucial (Uyarra et al., 2016; Rodríguez-Pose \& Wilkie, 2018).

The findings of this study open up important areas for future research, but should be taken as suggestive rather than definitive,. In particular, in an effort to complement firm-level studies, this paper has used city-level data. But investigating the interplay between firms and their local context would be an important contribution, particularly if it allowed the sources of innovation to be traced closer to their roots. Work using alternative indicators of innovation, such as trademarks, may see if these relationships extend beyond the technology-intensive indicators used here (Wojan et al., 2018; Castaldi, 2018). 


\section{References}

Acemoglu, D., Akcigit, U. and Celik, M.A., (2014). Young, restless and creative: Openness to disruption and creative innovations (No. w19894). National Bureau of Economic Research.

Archibugi, D., \& Pianta, M. (1996). Innovation surveys and patents as technology indicators: the state of the art. In: Innovation, Patents and Technological Strategies. OECD, Paris, pp. $17-50$

Atkinson, R., \& Easthope, H. (2009). The consequences of the creative class: The pursuit of creativity strategies in Australia's cities. International Journal of Urban and Regional Research, 33(1), 64-79.

Atkinson, R. D., \& Mayo, M. (2010). Refueling the US Innovation Economy: Fresh Approaches to Science, Technology, Engineering and Mathematics (STEM) Education. Washington, DC: Information Technology and Innovation Foundation.

Bakshi, H. \& McVittie, E. (2009). Creative supply chain linkages and innovation: Do the creative industries stimulate business innovation in the wider economy? Innovation: Management, Policy and Practice, 11(2),169-189.

Boschma, R. A., \& Fritsch, M. (2009). Creative class and regional growth: Empirical evidence from seven European countries. Economic Geography, 85(4), 391-423.

Brunow, S., Birkeneder, A., \& Rodríguez-Pose, A. (2018). Creative and science oriented employees and firm-level innovation. Cities, 78, 27-38.

Castaldi, C. (2018). To trademark or not to trademark: The case of the creative and cultural industries. Research Policy, 47(3), 606-616.

Clifton, N. (2008). The "creative class" in the UK: an initial analysis. Geografiska Annaler: Series B, Human Geography, 90(1), 63-82.

Duranton, G., \& Puga, D. (2001). Nursery cities: Urban diversity, process innovation, and the life cycle of products. American Economic Review, 91(5), 1454-1477.

Duranton, G., \& Puga, D. (2005). From sectoral to functional urban specialisation. Journal of Urban Economics, 57(2), 343-370.

Feldman, M. P., \& Audretsch, D. B. (1999). Innovation in cities: Science-based diversity, specialization and localized competition. European Economic Review, 43(2), 409-429.

Filippetti, A. (2011). Innovation modes and design as a source of innovation: a firm-level analysis. European Journal of Innovation Management, 14(1), 5-26.

Fitjar, R. D., \& Rodríguez-Pose, A. (2011). When local interaction does not suffice: sources of firm innovation in urban Norway. Environment and Planning A, 43(6), 1248-1267.

Florida, R. (2002). The rise of the creative class: and how it's transforming work, leisure, community and everyday life. New York: Basic.

Florida, R. (2003). Cities and the creative class. City \& Community, 2(1), 3-19. 
Florida, R. (2005). Cities and the creative class. London: Routledge

Florida, R. (2014). The rise of the creative class--revisited: Revised and expanded. New York: Basic Books.

Frick, S. A., Rodríguez-Pose, A., \& Wong, M. D. (2019). Toward Economically Dynamic Special Economic Zones in Emerging Countries. Economic Geography, 95(1), 30-64.

Gabe, T. M. (2006). Growth of Creative Occupations in US Metropolitan Areas: A ShiftShare Analysis. Growth and Change, 37(3), 396-415.

Glaeser, E. (2005). Review of Richard Florida's The Rise of the Creative Class. Regional Science and Urban Economics, 35(5), 593-596.

Grillitsch, M., Martin, R., \& Srholec, M. (2017). Knowledge base combinations and innovation performance in Swedish regions. Economic Geography, 93(5), 458-479.

Grillitsch, M., \& Nilsson, M. (2015). Innovation in peripheral regions: Do collaborations compensate for a lack of local knowledge spillovers?. The Annals of Regional Science, 54(1), 299-321.

Homeland Infrastructure Foundation. (2019). Open Data Platform. Available from: https://hifld-geoplatform.opendata.arcgis.com/ [Accessed 21 ${ }^{\text {st }}$ March 2019]

Houston, D., Findlay, A., Harrison, R., \& Mason, C. (2008). Will attracting the "creative class" boost economic growth in old industrial regions? A case study of Scotland. Geografiska Annaler: Series B, Human Geography, 90(2), 133-149.

Huggins, R., \& Clifton, N. (2011). Competitiveness, creativity, and place-based development. Environment and Planning A, 43(6), 1341-1362.

Jones, J. I. (2014). An overview of employment and wages in science, technology, engineering and math (STEM) groups. Between the Numbers $(3,8)$. Washington DC: Bureau of Labor Statistics.

Kotkin, J. (1997). Escape from Nerdistan. The Washington Post, September 14, 1997.

Lee, N. (2014). The creative industries and urban economic growth in the UK. Environment and Planning A, 46(2), 455-470.

Lee, N. and Drever, E. (2013). The creative industries, creative occupations and innovation in London. European Planning Studies, 21(12), pp.1977-1997.

Lee, N. (2015). Migrant and ethnic diversity, cities and innovation: Firm effects or city effects?. Journal of Economic Geography, 15(4), pp.769-796.

Lee, N., \& Rodríguez-Pose, A. (2014a). Creativity, cities, and innovation. Environment and Planning A, 46(5), 1139-1159.

Lee, N., \& Rodríguez-Pose, A. (2014b). Innovation in creative cities: Evidence from British small firms. Industry and Innovation, 21(6), 494-512. 
Lee, N., \& Rodríguez-Pose, A. (2016). Is there trickle-down from tech? Poverty, employment, and the high-technology multiplier in US cities. Annals of the American Association of Geographers, 106(5), 1114-1134.

Machlup, F. (1962). The production and distribution of knowledge in the United States (Vol. 278). Princeton: Princeton University Press.

Marshall, A. (1919). Industry and trade: A study of industrial technique and business organization. London: Macmillan.

Marlet, G., \& Van Woerkens, C. (2007). The Dutch creative class and how it fosters urban employment growth. Urban Studies, 44(13), 2605-2626.

Marrocu, E., \& Paci, R. (2012). Education or creativity: What matters most for economic performance?. Economic Geography, 88(4), 369-401.

Nathan, M., \& Lee, N. (2013). Cultural diversity, innovation, and entrepreneurship: Firmlevel evidence from London. Economic Geography, 89(4), 367-394.

Østergaard, C. R., Timmermans, B., \& Kristinsson, K. (2011). Does a different view create something new? The effect of employee diversity on innovation. Research Policy, 40(3), 500-509.

Peck, J. (2005). Struggling with the creative class. International Journal of Urban and Regional Research, 29(4), 740-770.

Qian, H. (2013). Diversity versus tolerance: The social drivers of innovation and entrepreneurship in US cities. Urban Studies, 50(13), 2718-2735.

Rodríguez-Pose, A., \& Wilkie, C. (2018). Strategies of gain and strategies of waste: What determines the success of development intervention?. Progress in Planning. https://doi.org/10.1016/i.progress.2018.07.001.

Rothwell, J., Lobo, J., Strumsky, D. and Muro, M. (2013) Patenting Prosperity: Invention and economic performance in the United States and its Metropolitan Areas. Brookings Metropolitan Policy Programme, available at: https://www.brookings.edu/wpcontent/uploads/2016/06/patenting-prosperity-rothwell.pdf

Ruggles, S., Flood, S., Goeken, R., Grover, J., Meyer, E., Pacas, J., \& Sobek, M. (2018). IPUMS USA: Version 8.0 [dataset]. Minneapolis, MN: IPUMS.

Sapsed, J., Nightingale, P., Camerani, R., Mateos-Garcia, J., Voss, G., Coad, A. and Byford, J., 2013. The Brighton Fuse. Swindon: Arts and Humanities Research Council.

Shearmur, R. (2015). Far from the madding crowd: Slow innovators, information value, and the geography of innovation. Growth and Change, 46(3), 424-442.

Siepel, J., Camerani, R., Masucci, M., \& Pellegrino, G. (2016). The fusion effect: the economic returns to combining arts and science skills. London: Nesta.

Sleuwaegen, L., \& Boiardi, P. (2014). Creativity and regional innovation: Evidence from EU regions. Research Policy, 43(9), 1508-1522. 
Spielman, S. E., \& Singleton, A. (2015). Studying neighborhoods using uncertain data from the American community survey: a contextual approach. Annals of the Association of American Geographers, 105(5), 1003-1025.

Stam, E., De Jong, J. P., \& Marlet, G. (2008). Creative industries in the Netherlands: Structure, development, innovativeness and effects on urban growth. Geografiska Annaler: Series B, Human Geography, 90(2), 119-132.

Storper, M., \& Venables, A. J. (2004). Buzz: face-to-face contact and the urban economy. Journal of Economic Geography, 4(4), 351-370.

Uyarra, E., Shapira, P., \& Harding, A. (2016). Low carbon innovation and enterprise growth in the UK: Challenges of a place-blind policy mix. Technological Forecasting and Social Change, 103, 264-272.

Vallance, P. (2015). Design employment in UK regional economies: Industrial and occupational approaches. Local Economy, 30(6), 650-671.

Vinodrai, T. (2006). Reproducing Toronto's design ecology: career paths, intermediaries, and local labor markets. Economic Geography, 82(3), 237-263.

Winters, J. V. (2014a). STEM graduates, human capital externalities, and wages in the US. Regional Science and Urban Economics, 48, 190-198.

Winters, J. V. (2014b). Foreign and native-born STEM graduates and innovation intensity in the United States. IZA DP No. 8575.

Wojan, T. R., Crown, D., \& Rupasingha, A. (2018). Varieties of innovation and business survival: Does pursuit of incremental or far-ranging innovation make manufacturing establishments more resilient?. Research Policy, 47(9), 1801-1810. 